Arq. Bras. Med. Vet. Zootec., v.66, n.2, p.613-616, 2014

\title{
Communication
}

[Comunicação]

\section{Viable offspring after successful non-surgical embryo transfer in goats}

[Nascimento de fetos viáveis após transferência de embriões não-cirúrgica em caprinos]

\author{
J.F. Fonseca ${ }^{1}$, L.V. Esteves ${ }^{2}$, F.N. Zambrini ${ }^{3}$, F.Z. Brandão ${ }^{2}$, M.G.C.D. Peixoto ${ }^{4}$, R.S. Verneque ${ }^{4}$, \\ L.G.B. Siqueira ${ }^{4}$ J.H.M. Viana ${ }^{4}$
}

\author{
${ }^{1}$ Embrapa Caprinos e Ovinos - Núcleo Regional Sudeste - CEJHB-Embrapa Gado de Leite - Coronel Pacheco, MG \\ ${ }^{2}$ Faculdade de Medicina Veterinária - Universidade Federal Fluminense - Niterói, RJ \\ ${ }^{3}$ Universidade Federal de Viçosa - Viçosa, MG \\ ${ }^{4}$ Embrapa Gado de Leite - Juiz de Fora, MG
}

It has been more than 100 years since the first successful embryo transfer (ET) was reported in rabbits by Heape in 1890. In goats, Warwick et al. (1934) reported the first kid born after the use of ET. Since then, small ruminants have been in ET programs around the world, but need for surgical procedures has limited a greater expansion of the ET industry in those species. Brazil is a good example that this scenario can be changed. In this country, near to $100 \%$ of commercial goat embryos transferred to recipients in 2010 were recovered via transcervical (Fonseca et al., 2010). Likewise, the same pattern is now observed in the Brazilian market of sheep embryos, after new cervical relaxation procedures have been developed and applied under field conditions to allow transcervical embryo recovery in donor ewes (Gusmão et al., 2009).

Given the efficiency of uterine flushing by the cervical route and also the reduced anesthesia and surgical risks or sequels, we believe that surgical embryo recovery will be gradually restricted or even prohibited. Considering that goat embryos recovery by the cervical route has been described before (Fonseca et al., 2013), and following the history of the cattle embryo industry, we are now focused on transcervical embryo transfer in small ruminants, the last step of the entire procedure. It is well known that sheep cervices present very complex and variable morphology (Anel et al., 2006), which is a great barrier to transcervical procedures. On the other hand, in goats, once the cervix is immobilized, a catheter can be easily passed through the cervical rings after prostaglandin priming (treatment) (Fonseca et al., 2011). Thus, the objective was to test the possibility and feasibility of non-surgical embryo transfer in recipient goats without drugs for cervical relaxation.

This study was carried out during the local nonbreeding season (November) in Coronel Pacheco, Minas Gerais, southeast region of Brazil. The research unit is located at $435 \mathrm{~m}$ altitude, $21^{\circ} 35^{\prime} \mathrm{S}$ and $43^{\circ} 15^{\prime} \mathrm{W}$ latitude and longitude, respectively. The area receives an average annual precipitation of $1581 \mathrm{~mm}^{3}$. Average annual temperature experienced at this site was $21^{\circ} \mathrm{C}$. This research was reviewed and approved by the Animal Care Committee of Universidade Federal Fluminense (UFF / 01162011) and it is under the ethical principles of SBCAL (Sociedade Brasileira de Ciência em Animais de Laboratório).

Two lactating Toggenburg goats (donors) and 10 pluriparous non-lactating Toggenburg goats (recipients) were enrolled in this study. The mean body weight and condition score (scale 1 to 5) were $76.8 \pm 4.7 \mathrm{~kg}$ and $3.8 \pm 0.2$, respectively. Animals were managed in an intensive system receiving maize silage and a protein concentrate according to their maintenance demand. Mineral and water were offered ad libitum.

Recebido em 19 de abril de 2013

Aceito em 28 de novembro de 2013

E-mail: jeferson.fonseca@embrapa.br 
Non-surgical uterine flushing was performed using the cervical route in both donors. One of the donors received a superovulation treatment before uterine flushing, whereas the other one did not receive any treatment. Embryos were recovered six to seven days after the first breeding using the transcervical technique as described by Fonseca et al., (2013). Embryos were classified according to the stage of development and quality as proposed by the IETS manual (International Embryo Transfer Society; Stringfellow and Seidel, 1999).

Ten non-lactating pluriparous Toggenburg goats were induced to estrus by a combination of progestagen/prostaglandin/eCG in a six day protocol (Fonseca et al., 2005). Copora lutea (CL) were detected one day before embryo transfer by transrectal ultrasonography. Seven days after estrous detection, females presenting $\mathrm{CL}$ in one ovary were selected to test the efficiency of embryo deposition. Four does were used, for that purpose, two received a pair of embryos and the other two received one embryo only. A $5 \mathrm{~mL}$ syringe with $2 \mathrm{~mL}$ of PBS medium was coupled to a tom cat catheter, so that the embryos were aspirated into the central within three columns of the tom cat catheter. A number 2 Collin speculum was inserted into the vulva until reach the vagina fornix and, with the aid of a light source, the cervix was visualized and immobilized using two $26 \mathrm{~cm}$ Allis forceps clipped on and under the cervical opening. A number six urethral catheter with a mandrel was humidified with PBS medium and inserted into the cervix and the cervical rings were gently transposed. After lost of resistance, the urethral catheter was moved laterally to reach the desired uterine horn. Both the mandrel and the two Allis forceps were removed; the syringe/tom cat device was attached to the urethral catheter; the embryos were transferred to the uterine horn ipsilateral to the ovary bearing the CL; and, finally, the urethral catheter was removed.

Transrectal ultrasonography was performed 23 days after embryo transfer (30 days gestation) to visualize intrauterine content, the embryonic vesicle, and fetal heart beat, as a confirmation of pregnancy. The partum was assisted.

The following parameters were recorded: embryo morphology and quality; number and location of corpora lutea; interval from speculum insertion to its removal; time elapsed for cervical transposition; pregnancy, offspring survival, and parturition rates.

Results are summarized in Table 1. The seven ova/embryo collected were classified as: nonfertilized (NF; $n=1$ ), compact morulae (Mc; $\mathrm{n}=3$ ), and blastocyst $(\mathrm{Bl} ; \mathrm{n}=3$ ) embryos. Embryo quality varied from grade 1 (excellent) to 3 (regular). The interval from speculum insertion to its removal was inferior to three minutes, whereas the period of time to transpose the cervix was less than one minute. Ultrasonography at Day 30 confirmed that all embryos transferred reached the desired uterine horn, i. e., the fetuses were visualized in the same horn as recorded during embryo transfer. Two (50\%) of the four recipients became pregnant and gave a birth to three kids.

Table 1. Records from recipient goats that received embryos by non-surgical transfer (via transcervical)

\begin{tabular}{lccccc}
\hline \multirow{2}{*}{ Parameter } & \multicolumn{5}{c}{ Recipients } \\
\cline { 2 - 6 } & ${ }^{\#} 8729$ & 8745 & \# $8746^{*}$ Total \\
\hline Number of corpora lutea & 3 & 2 & 1 & 2 & 8 \\
Ovary / uterine horn & Left & Left & Left & Left & - \\
Embryos transferred & Mc-1* & B1-1+Mc-3 & B1-1+Mc-3 & B1-1 & 6 \\
Survival rate $(\%)$ & $0.0(0 / 1)$ & $100.0(2 / 2)$ & $50.0(1 / 2)$ & $0.0(0 / 1)$ & $50.0(3 / 6)$ \\
\hline
\end{tabular}

${ }^{\#}$ Ear-tag number of each recipient. * Embryo morphology and quality. ( ) Number of embryos.

From 10 goats which estrus was induced, four were selected for ovulation in only one ovary. Since Ginther and Kot (1994) revealed the possibility of real time ultrasonography for monitoring ovarian follicular dynamic in goats, many studies have been developed on ovarian follicle growth (Menchaca et al., 2002) and ovulation (Menchaca and Rubianes, 2004). In addition, our group have previously monitored the development of copora lutea during the estrous cycle in pregnant and non-pregnant goats (Arashiro et al., 2010). This last study attested/confirmed the efficiency of ultrasonography to detect CL on day 6 of the 
estrous cycle, which was required for a precise localization of the CL in goats used as embryo recipients. One of the key points to perform embryo transfer by laparoscopy is an accurate CL identification. By using ultrasonography, this could also be applied to the non-surgical embryo goat transfer. Moreover, the procedures for transcervical artificial insemination previously developed by our group (Fonseca et al., 2011), which were performed with goat in the standing position, enabled us to easily locate, evaluate, immobilize, and transpose the cervix. The use of these concepts in a similar way gave us the support to try the transcervical embryo transfer as well.

Transcervical embryo recovery can be efficiently performed (Fonseca et al., 2013) and can replace laparotomy or laparoscopic recovery in goats. Numerous advantages were previously described (Fonseca et al., 2011), including no needs for food and water restriction, animal welfare, and health care as the most important reasons to eliminate complex anesthesia and surgical procedures. Throughout the entire procedure of embryo transfer, females did not present behavioral signs of pain, e.g., vocalization and postural discomfort. In general, their behavior was similar to that observed during other routine activities, such as traditional artificial insemination and ultrasonographic examinations. Considering that no anesthesia was used, it was expected that there was some degree of pain. However, we also expected that this pain or discomfort was lower than those expected during procedures for local or general anesthesia used in surgical ET. Also, the distress that animals experience after the end of the anesthetic drugs effects was absent when the non-surgical ET was used. Finally, no lesions, wounds, and blood was seen during and after the transcervical embryo transfer

The present study reported the possibility of altering the last step of embryo transfer in small ruminants, the transfer itself, from surgical to a non-surgical procedure. The ET procedure currently described was quick and selfperformed. Before, the use of laparoscopy was a requisite, and the risks associated to the techniques were similar to any other surgical process. In the present study, by using nonsurgical ET, we observed a 50\% parturition rate, which open a promissory window for the goat embryo transfer industry, that can now apply ET procedures under field conditions in less laborious way. Further studies may confirm the feasibility of non-surgical ET in large scale operations. If so, embryo transfer in goats will be performed in a very similar way to the correspondent technique in cattle. Finally, the technique reported in this study could be performed and applied in field conditions in the near future to lead and conserve breeds in locals where infrastructure is restricted, such as those still observed in Latin America, Asia, and Africa.

These are the first results from a series of nonsurgical embryo transfer program in Brazil. The reported technique was simple and quickly performed, and allowed an efficient embryo deposition direct to the desired uterine horn, after CL location. Further, studies are still needed in large scale. However, when feasibility is confirmed, it can definitely change embryo transfer procedures in goats.

Keywords: goat, non-surgical embryo transfer, cervical via

\section{RESUMO}

O objetivo do presente estudo foi avaliar a viabilidade da técnica de transferência não cirúrgica em cabras. Quatro cabras não-lactantes pluríparas da raça Toggenburg foram utilizadas como receptoras de embriões, sendo que duas receberam um embriões e duas receberam dois embriões coletados não cirurgicamente cabras doadoras. Os corpos lúteos das receptoras foram detectados um dia antes da transferência de embriões por ultrassonografia transretal. Uma seringa de $5 \mathrm{~mL}$ contendo $2 \mathrm{~mL}$ de meio holding foi acoplada em um cateter tomcat, no qual os embrioes foram aspirados em uma coluna central a duas outras colunas. Um espéculo Colin número 2 foi inserido na vulva e na vagina, e com o uso de uma fonte de luz, a cerviz foi localizada e imobilizada com uma pinça de Allis. Um cateter uretral número seis acoplado a um mandril e lubrificado com meio PBS foi inserido na cérvix, e assim os aneis cervicais foram gradualmente transpostos. Após perder a resistência, o cateter uretral foi movido lateralmente para o corno uterino desejado. O mandril e a pinça de Allis foram retirados e o conjunto 
seringa e tomcat foi acoplado ao cateter uretral e o conteúdo injetado no corno uterino ipsilateral ao corpo lúteo com posterior retirada do cateter. Cabras que ovularam em apenas um ovário foram usadas para testar a eficiência da deposição do embrião. O tempo gasto entre a inserção do espéculo e a sua remoção foi inferior a três minutos. O tempo para transpor a cérvix foi inferior a um minuto. A ultrassonografia revelou a deposição de líquido no corno desejado. Receptoras que receberam dois embriões tornaram-se gestantes e pariram três crias. Estes primeiros resultados encorajam a técnica e demonstram que a transferência de embriões em caprinos pode ser feita totalmente por procedimentos não cirúrgicos.

Palavras-chave: cabra, transferência de embriões não cirúrgica, via cervical

\section{ACKNOWLEDGMENTS}

The authors thank to Dr José Henrique Bruschi (in memorian) and $\operatorname{Dr}$ Marlene Bruschi from Agropecuária Água Limpa for providing animals, animal housing and feeding, Empresa Brasileira de Pesquisa Agropecuária (EMBRAPA; Project 01.07.01.002.05), and Fundação de Amparo à Pesquisa de Minas Gerais (FAPEMIG, Project CVZ-APQ 01367/09) for the financial support to this study. JFF, FZB and RSV are CNPq fellows.

\section{REFERENCES}

ANEL, L.; ALVAREZ, M.; MARTINEZPASTOR, F. et al. Improvement strategies in ovine artificial insemination. Reprod. Dom. Anim., v.41, p.30-42, 2006.

ARASHIRO, E.K.; FONSECA, J.F.; SIQUEIRA, L.G.B. et al. Assessment of luteal function in goats by ultrasonographic image attribute analysis. Small Rumin. Res., v.94, p.176-179, 2010.

FONSECA, J.F.; BRUSCHI, J.H.; ZAMBRINI, F.N. et al. Induction of synchronized estrus in dairy goats with different gonadotrophins. Anim. Reprod. v.2, p.50-53, 2005.

FONSECA, J.F.; OLIVEIRA, M.E.; VIANA, J.H. Uso de procedimentos não cirúrgicos para a produção, recuperação e inovulação de embriões em pequenos ruminantes. Rev. Bras. Reprod. Anim., v.35, p.113-117, 2011.

FONSECA, J.F.; SOUZA, J.M.G.; CAMARGO, L.S.A. Produção de oócitos e embriões de pequenos ruminantes: passado, presente $\mathrm{e}$ futuro. Acta Sci. Vet., v.38, ,p.337-369, 2010.
FONSECA, J.F.; ZAMBRINI, F.N.; ALVIM, G.P. et al. Embryo production and recovery in goats by non-surgical transcervical technique. Small Rumin. Res., v.111, p.96-99, 2013.

GINTHER, O.J.; KOT, K. Follicular dynamics during the ovulatory season in goats. Theriogenology, v.42, p.987-1001, 1994.

GUSMÃO A.L.; SILVA J.C.; BITTENCOURT T.C.C. et al. Coleta transcervical de embriões em ovinos da raça Dorper no semiárido do Nordeste Brasileiro. Arq. Bras. Med. Vet. Zootec., v.61, p.313-318, 2009.

MENCHACA, A.; RUBIANES, E., Relation between progesterone concentrations during the early luteal phase and follicular dynamics in goats. Theriogenology, v.57, p.1411-1419, 2002.

MENCHACA, A.; RUBIANES, E. New treatments associated with timed artificial insemination in small ruminants. Reprod. Fertil. Devel., v.16, p.403-413, 2004.

STRINGFELLOW, D.A.; SEIDEL, S.M. Manual da Sociedade Internacional de Transferência de Embriões. Savoy: IETS, 1999. 145p.

WARWICK, B.L.; BERRY, R.O.; HORLACHER, W.R. Results of mating rams to Angora female goats. In: PROCEEDINGS OF THE AMERICAN SOCIETY OF ANIMAL PRODUCTION, 27., 1934, p.225-227. 